\title{
Plasmids isolated from the sugar beet phyllosphere show little or no homology to molecular probes currently available for plasmid typing
}

\author{
Nobuharu Kobayashi† and Mark J. Bailey \\ Author for correspondence: Mark J. Bailey. Tel: +44865 512361. Fax: + 4486559962.
}

Natural Environment

Research Council, Institute of Virology and

Environmental

Microbiology, Mansfield

Road, Oxford OX1 3SR, UK

\begin{abstract}
From a representative sample of bacteria, isolated from mature sugar beet leaves (Beta vulgaris) grown at three separate locations in the UK, 79 (18\%) were shown to contain plasmids ranging in size from $10 \mathrm{~kb}$ to $200 \mathrm{~kb}$. A sensitive colony blot method was developed to facilitate the screening of both Gram-negative and Gram-positive isolates to determine the distribution of known plasmid incompatibility groups among plasmids isolated from the natural environment using the collection of inc/rep probes derived from basic replicons [rep FIA, FIIA, FIB, HI1, HI2, I1, B/O, LIM, N, P, Q, U, W and X, as described by Couturier et al. (1988) Microbiol Rev 52, 375-395]. After hybridization with each of the radiolabelled replicon probes, 54 of these 79 plasmid-containing natural isolates, which included Erwinia spp., Pseudomonas spp. and Gram-positive bacteria, failed to react. Reactivity was observed with $\mathbf{2 5}$ of the $\mathbf{2 9}$ Klebsiella and Erwinia isolates investigated. Of the plasmidcontaining Enterobacteriaceae examined, 18 reacted with the repFIB probe, six with the repFIIA probe and one isolate, Erwinia salicis SBN169, hybridized to both. Southern hybridization demonstrated that the different isolates which shared homology with the repFIB probe contained a common 1 kb PstI fragment. By comparing the Pstl restriction fragment patterns of total plasmid DNA, the Erwinia and Klebsiella isolates were divided into 10 distinct groups and the other non-reactive isolates divided into a further $\mathbf{2 4}$ groups. Plasmid type appeared to be restricted to the geographical location from which the host bacteria were isolated. This study illustrates that sugar beet phyllosphere bacteria support a diverse array of plasmids which cannot be readily classified at the molecular level into the recognized incompatibility groups commonly described for clinical isolates.
\end{abstract}

Keywords: incompatibility, plasmids, leaf epiphytes, replicon typing

\section{INTRODUCTION}

Knowledge of the abundance, distribution and diversity of plasmids in microbial populations is important for understanding bacterial gene flux. This is especially relevant to the concerns expressed that exogenous genetic material, introduced in genetically modified microorganisms (GMM()s), might be transferred to the detriment of the environment. Methods for investigating

†Present address: Department of Bacteriology, Saitama Medical School, Moroyama, Saitama 350-04, Japan. plasmid distribution have been described which rely either on demonstrating physical presence (endogenous isolation) or selection on the basis of a transferred phenotype (exogenous isolation). Endogenous methods require the isolation and chemical lysis of cells and the separation of plasmid DNA by electrophoresis. Although exogenous methods are independent of the need to isolate the natural host bacterium, they rely on the expression of resistance to antibiotics, heavy metals or other selectable traits (Fry \& Day, 1990). In addition, broad host-range, non-conjugative mobilizable reporter plasmids have been used to demonstrate the presence of transfer-proficient plasmids in isolates sampled from natural habitats (Powell 
et al., 1993; Hill et al., 1992) or to model plasmid transfer in situ (Top et al., 1990). However, many plasmids remain cryptic and assessment of their diversity solely on the basis of transfer activity can be limiting, although important for estimating the potential for gene mobilization. Therefore, before the distribution of natural plasmids can be accurately studied, methods must be developed to facilitate their initial detection and description. The approach described here assesses the degree of conservation of regions of plasmid replication and maintenance in isolates collected from the sugar beet phyllosphere.

Plasmids with similar replication control systems are defined as incompatible and cannot be maintained in the same host cell (Datta, 1979; Novick, 1987), a characteristic which has been used to classify plasmids into approximately 30 incompatibility groups (Bergquist, 1987). Although useful for classification, the incompatibility grouping of plasmid isolates normally involves mating and transfer methods which are laborious and require the presence of suitable markers on the plasmids under evaluation. In an attempt to facilitate plasmid classification, unique DNA sequences corresponding to the origins of replication and incompatibility loci of a number of well described plasmids have been identified and isolated (Davey et al., 1984; Couturier et al., 1988). Wherever possible, loci involved in plasmid copy number, rather than partition loci, were chosen as they are highly conserved in plasmids so far investigated. This method has been referred to as 'replicon typing' and its value for the identification of plasmids and their incompatibility groups in bacterial isolates of medical importance has been demonstrated (Couturier et al., 1988). It is unknown whether these incompatibility group or replicon probes are representative of all bacterial plasmids or restricted to plasmids present only in bacteria isolated from the clinical and animal environment, from which they were originally derived.

In a previous investigation into the transfer potential of plasmids indigenous to the sugar beet leaf habitat we demonstrated that $18 \%$ of a random sample of 435 isolates, collected from three different geographical areas, contained plasmid DNA (Powell et al., 1993). These isolates included a range of genera considered to be representative of both Gram-negative (Erwinia, Klebsiella, Pseudomonas) and Gram-positive (Micrococcus and Brevibacterium) aerobic heterotrophs, known to be common to the phyllosphere bacterial community of mature sugar beet plants (Thompson et al., 1993). The diversity of this sample provided a suitable range of isolates to assess the extent to which well defined incompatibility loci are conserved in plasmids isolated from the terrestrial environment.

\section{METHODS}

Bacterial strains, identification and growth conditions. The natural bacterial strains examined were isolated from the leaves of sugar beet plants grown at three separate locations in the UK and have been described previously (Powell et al., 1993). Bacteria were identified by comparative gas chromatographic analysis of cellular fatty acid methyl esters (FAME) using Microbial Identification System's 'Aerobe library' version 3.3 (MIDI, Microbial ID, Newark, USA), as described by Stead et al. (1992). All isolates were stored at $-70^{\circ} \mathrm{C}$ in $30 \%(\mathrm{v} / \mathrm{v})$ glycerol-saline and grown in tryptic soy broth at $28^{\circ} \mathrm{C}$. Escherichia coli and Pseudomonas spp. control strains (Table 1 ) were grown in Lbroth at $37^{\circ} \mathrm{C}$ or $28^{\circ} \mathrm{C}$, respectively, and plasmid-containing strains were grown in L-broth amended with the appropriate antibiotics.

Inc/rep probes used in replicon typing. E. coli strains containing plasmids into which the incompatibility loci had been inserted were a gift from Professor W. K. Maas (Department of Microbiology, New York School of Medicine) and Dr M. Couturier (Department of Molecular Biology, Université Libre de Bruxelles). Plasmids were purified by $\mathrm{CsCl}$ gradient centrifugation, and digested with the appropriate restriction endonucleases as described by Couturier et al. (1988). DNA fragments containing the inc/rep regions were eluted from low melting point agarose with Geneclean (Bio 101). The isolated DNA fragment was labelled by nick-translation using $[\alpha-$ $\left.{ }^{32} \mathrm{P}\right] \mathrm{dATP}$ (Amersham), purified on Nunctrap push columns (Stratagene) and used as probes. Fourteen unique probes [rep FIA (917 bp), FIIA (543 bp; cross reacts with com9 and incFIC), FIB (1202 bp), HI1 (2250 bp), HI2 (1800 bp), I1 (100 bp; cross reacts with incFIC and inc $\mathrm{B} / \mathrm{O}), \mathrm{B} / \mathrm{O}(1600 \mathrm{bp}$; cross reacts with incFIC, incI1 and incK), L/M (800 bp), N (1000 bp), P (750 bp), Q (357 bp), U (950 bp), W (1150 bp) and X (942 bp)] (Couturier et al., 1988) were prepared and applied to the available samples and controls as described.

Colony hybridization. The natural isolates containing plasmids were inoculated in a grid pattern on nylon membranes (Hybond$\mathrm{N}$, Amersham, UK) supported on Tryptic Soy Broth agar plates [TSBA; Tryptone Soy Broth (Difco) and 1.5\% (w/v) Agar No. 1 (Oxoid)] and incubated at $28{ }^{\circ} \mathrm{C}$ overnight. Controls of plasmid-free and plasmid-containing bacteria were included (Table 1). After incubation, cells were lysed by placing membranes, colony side up, on Whatman 3MM filter paper soaked with $2 \times \mathrm{SSC}, 5 \%(\mathrm{w} / \mathrm{v})$ SDS for $2 \mathrm{~min}$, followed by heating at maximum power in a $650 \mathrm{~W}$ microwave oven for $2.5 \mathrm{~min}$, as described by Buluwela $e t$ al. (1989) and Frischer $e t$ al. (1990). The membranes were transferred to filter paper soaked with denaturing solution $(0.5 \mathrm{M} \mathrm{NaOH}, 1.5 \mathrm{M} \mathrm{NaCl})$ and incubated for a further $7 \mathrm{~min}$. The denaturing step was repeated and followed by two neutralization steps on filter paper soaked with $0.5 \mathrm{M}$ Tris $/ \mathrm{HCl}, \mathrm{pH} 7.0,1.5 \mathrm{M} \mathrm{NaCl}$ for $5 \mathrm{~min}$. The released DNA was air-dried onto the filter and heated in the microwave oven for $1 \mathrm{~min}$. Membranes were washed in prewarmed $\left(42^{\circ} \mathrm{C}\right)$ $2 \times$ SSC solution and prehybridized in $10 \mathrm{ml}$ hybridization solution (Maniatis $e$ t al., 1982) containing $50 \%(\mathrm{v} / \mathrm{v})$ formamide at $42^{\circ} \mathrm{C}$ for $5 \mathrm{~h}$. Radiolabelled probes $\left(2 \times 10^{6}\right.$ c.p.m. $\left.\mathrm{ml}^{-1}\right)$, in hybridization solution, were incubated at $42{ }^{\circ} \mathrm{C}$ for $16 \mathrm{~h}$. Unbound label was removed from the membranes by washing once in $4 \times \mathrm{SSC}, 0.1 \%$ SDS, twice in $2 \times \mathrm{SSC}, 0.1 \%$ SDS and twice in $0.1 \times \mathrm{SSC}, 0.1 \% \mathrm{SDS}$ at $65^{\circ} \mathrm{C}$. Membranes were dried and exposed to $\mathrm{X}$-ray films at $-70^{\circ} \mathrm{C}$ for $2 \mathrm{~d}$.

Dot-blot hybridization. Total genomic DNA was extracted from a $1.5 \mathrm{ml}$ overnight culture of each sample essentially as described by Ausubel et al. (1989). The method was modified to facilitate DNA extraction from Gram-positive isolates by applying two thermal shock steps to the washed pellet of cells prior to treatment with proteinase $\mathrm{K}$. The cell pellet was snap frozen in liquid nitrogen, thawed at $65^{\circ} \mathrm{C}$, refrozen and thawed. Samples $(50 \mu \mathrm{l})$ of the purified DNA were serially diluted in water, denatured with an equal volume of denaturing buffer 
Table 1. Plasmids and bacterial strains used as controls in the hybridization assays

\begin{tabular}{|c|c|c|c|}
\hline Strain & Plasmid & $\begin{array}{l}\text { Inc } \\
\text { group }\end{array}$ & Reference \\
\hline $\begin{array}{l}\text { Pseudomonas putida } \\
\text { LWC1 }\end{array}$ & - & - & McClure et al. (1989) \\
\hline P. putida UWC1 & RP4 & IncP & \\
\hline $\begin{array}{l}\text { P. aureofaciens } \\
\text { SBW } 25^{*}\end{array}$ & - & & $\begin{array}{l}\text { Bailey \& Thompson } \\
\text { (1992) }\end{array}$ \\
\hline P. aureofaciens $\mathrm{SBW} 25$ & $\mathrm{R} 300 \mathrm{~B}$ & IncQ & \\
\hline Erwinia berbicola Eh5* & & & This study \\
\hline Er. berbicola Eh5 & $\mathrm{R} 300 \mathrm{~B}$ & IncQ & \\
\hline Er. berbicola Eh5 & pBR322 & $?$ & Maniatis et al. (1982 \\
\hline \multicolumn{4}{|l|}{ Escherichia coli HB10I } \\
\hline E. coli HB101 & pBR322 & $?$ & \\
\hline E. coli HB101 & RP4 & IncP & \\
\hline E. coli HB101 & $\mathrm{R} 300 \mathrm{~B}$ & IncQ & \\
\hline E. coli CM444 & $\mathrm{R} 388$ & IncW & \\
\hline
\end{tabular}

*P. aureofaciens SBW25 and Er. herbicola Eh5, plasmid-free bacterial isolates collected from the leaf surface of sugar beet plants grown at Wytham, Oxfordshire.

$\left(500 \mathrm{mM} \mathrm{NaOH}, 104 \mathrm{mM} \mathrm{NaCl}\right.$ ), incubated at $95^{\circ} \mathrm{C}$ for $10 \mathrm{~min}$ and neutralized with $100 \mu \mathrm{l}$ ice-cold $2 \mathrm{M}$ ammonium acetate. The DNA was dispensed in $50 \mu \mathrm{l}$ volumes to the wells of a BioDot microfiltration apparatus (Bio-Rad) containing a nylon membrane prewetted in $1 \mathrm{M}$ ammonium acetate. After filtration the membranes were washed in $2 \times \mathrm{SSC}$, dried and reacted with probe as described above.

Plasmid extraction from natural isolates. Plasmids were extracted from all the available natural isolates by a modification of the method of Kado \& Liu (1981) as described by Ohta et al. (1989) unless otherwise stated. Plasmid DNA collected by centrifugation was washed twice by resuspension in $200 \mu \mathrm{l}$ washing buffer $(50 \mathrm{mM}$ Tris $/ \mathrm{HCl}, \mathrm{pH} 8.0,100 \mathrm{mM}$ sodium acetate) and precipitated with $1 \mathrm{ml}$ ethanol. The extracted plasmids were resuspended in distilled water $(20-50 \mu \mathrm{l})$ and digested with $P_{s t} \mathrm{I}$ according to the manufacturer's instructions (BCL). Vigorous mixing was avoided during the plasmid extraction as the generation of a vortex by mechanical mixing greatly reduced the efficiency of plasmid separation from chromosomal DNA. DNA fragments were separated by electrophoresis in $0.8 \%(\mathrm{w} / \mathrm{v})$ agarose gels in TBE buffer (Maniatis $e t$ al., 1982). After staining in ethidium bromide solution $(0.5 \mu \mathrm{g}$ $\left.\mathrm{ml}^{-1}\right)$, plasmid profiles were observed with a transilluminator (UV Products, UK) and photographed. The plasmid profiles were recorded with a Summagraphics data tablet and fragment sizes determined using MolMatch computer software (UV Products, UK) against $\lambda$ DNA cut with EcoRI and HindIII molecular mass standards. The aggregate size of the total plasmid DNA in each isolate was calculated.

Southern hybridization of inc/rep probe reactive plasmids. After electrophoresis, gels were denatured, neutralized and blotted onto nylon membrane (Hybond-N, Amersham) using standard protocols (Maniatis et al., 1982). Blotted membranes were fixed under UV light for 3-5 min (Transilluminator, UV Products, UK) and hybridized as described above for the colony

Table 2. Characterization of plasmids isolated from Enterobacteriaceae indigenous to the phyllosphere of sugar beet

Isolates were from a pooled mature leaf sample collected at each site. Bacteria were identified by FAME-MIS (Stead $e t$ al., 1992).

\begin{tabular}{|c|c|c|c|c|c|}
\hline $\begin{array}{l}\text { Code } \\
(\mathrm{SB})^{*}\end{array}$ & $\begin{array}{c}\text { Host } \\
\text { speciest }\end{array}$ & $\begin{array}{l}\text { Inc/rep } \\
\text { group }\end{array}$ & $\begin{array}{c}\text { REN } \\
\text { group } \ddagger\end{array}$ & $\begin{array}{c}\text { Plant } \\
\text { source } \$\end{array}$ & $\begin{array}{c}\text { Size } \\
(\mathrm{kb}) \|\end{array}$ \\
\hline 130 & $\mathrm{Eh}$ & FIB & A & Nor & 150 \\
\hline $139(140,142,146)[4]$ & Eh & FIIA & Bg & Nor & 110 \\
\hline 153 & $\mathrm{Eh}$ & FIIA & $\mathrm{Cg}$ & Nor & 60 \\
\hline 169 & Es & FIIA/FIB & $\mathrm{D}$ & Nor & 100 \\
\hline $170(171,172,337)[4]$ & Eh & FIB & $E$ & Nor & 90 \\
\hline $175(178 a)[2]$ & $\mathrm{Er}$ & $?$ & $\mathrm{~F}$ & Nor & 65 \\
\hline $178 \mathrm{~b}$ & $\mathrm{Eh}$ & FIIA & G & Nor & 150 \\
\hline $\begin{array}{l}2(3,407-411,358,368 \\
369,376[11]\end{array}$ & $\mathrm{Kt}$ & FIB & $\mathrm{H}$ & $\mathrm{W}_{y t}$ & 130 \\
\hline 353 & Eh & FIB & I & $\mathrm{W}_{y t}$ & 195 \\
\hline $\begin{array}{l}385 \\
(n=27)\end{array}$ & Eh & FIB & $\begin{array}{c}\mathrm{J} \\
(n=10)\end{array}$ & $\mathrm{W}_{\mathrm{yt}}$ & 180 \\
\hline
\end{tabular}

* Code relates to the isslate number from which plasmid DNA was extracted. The number of identical isolates collected is indicated in square brackets.

† Eh, Er. herbicola - 4 , Er. salicis; Kt, K. terrigena.

$\ddagger$ Plasmid group determined by comparison of the total plasmid DNA profile after digestion with PstI. Each isolate may contain more than one plasmid.

\Field site from which the samples were collected; Nor, Northampton; Wyt, Wytham, Oxfordshire.

$\|$ Approximate size of total plasmid DNA, aggregate of REN fragments (Fig. 1).

9 REN group C Pst I ragment pattern identical to a subset in REN group B. 
Table 3. Natural plasmid-containing strains isolated from mature sugar beet leaves that did not hybridize with the available replicon probes

The 52 plasmid-containing isolates that failed to hybridize with the inc/rep replicon probes (Couturier et al., 1988) were further characterized by the total plasmid DNA profile generated after Pst I digestion and agarose gel electrophoresis. Insufficient DNA was isolated from 15 isolates (ND), 37 isolates were grouped into 24 different total plasmid DNA profile groups. Inc/rep probes used: FIA, FIIA, FIB, HI1, HI2, I1, B/O, L/M, N, P, Q, U, W and $\mathrm{X}$.

\begin{tabular}{|c|c|c|c|c|}
\hline $\begin{array}{l}\text { Code } \\
\text { (SB)* }\end{array}$ & $\begin{array}{c}\text { Host } \\
\text { species } \dagger\end{array}$ & $\begin{array}{c}\text { REN } \\
\text { group } \ddagger\end{array}$ & $\begin{array}{c}\text { Plant } \\
\text { source } \S\end{array}$ & $\begin{array}{c}\text { Size } \\
(\mathbf{k b}) \|\end{array}$ \\
\hline \multicolumn{5}{|l|}{ Gram-negative isolates } \\
\hline 43 & $\mathrm{~Pa}$ & ND & Nor & ND \\
\hline 68 & $\mathrm{Pp}$ & ND & Nor & ND \\
\hline 144 & $\mathrm{Ac}$ & $\mathrm{K}$ & Nor & 40 \\
\hline 266 & $\mathrm{Pp}$ & $\mathrm{L}$ & Nor & 15 \\
\hline $\begin{array}{l}288(290,292,294,295, \\
296,297)[7]\end{array}$ & $\mathrm{Pc}_{\mathrm{c}}$ & $\mathrm{M}$ & Nor & 70 \\
\hline 289 & Ps & ND & Nor & ND \\
\hline 426 & Eh & ND & Nor & ND \\
\hline $56(63)[2]$ & $\mathrm{Pc}$ & $\mathrm{N}$ & Som & 10 \\
\hline 57 & $\mathrm{Pp}$ & ND & Som & ND \\
\hline 58 & $\mathrm{~Pa}$ & ND & Som & ND \\
\hline 60 & $\mathrm{Eh}$ & ND & Som & ND \\
\hline 93 & $\mathrm{Pc}$ & ND & Som & ND \\
\hline 116 & $\mathrm{Xm}$ & $\mathrm{O}$ & Som & 10 \\
\hline $212(216,223)[3]$ & $\mathrm{Pv}$ & $\mathrm{P}$ & Som & 200 \\
\hline 213 & Ps & Q & Som & 60 \\
\hline 215 & $\mathrm{Pp}$ & ND & Som & ND \\
\hline $229(245)[2]$ & $\mathrm{Pm}$ & $\mathrm{R}$ & Som & 70 \\
\hline $231(232)[2]$ & Ps & $\mathrm{S}$ & Som & 30 \\
\hline 14 & $\mathrm{Ae}$ & $\mathrm{T}$ & Wyt & 20 \\
\hline 15 & Ac & $\mathrm{U}$ & Wyt & 25 \\
\hline 317 & Pf & ND & Wyt & ND \\
\hline $340(393)[2]$ & $\mathrm{Pf}$ & $\mathrm{V}$ & Wyt & 45 \\
\hline 413 & $\mathrm{~Pa}$ & ND & Wyt & ND \\
\hline \multicolumn{5}{|l|}{ Gram-positive isolates } \\
\hline $424(425)[2]$ & NM & $\mathrm{X}$ & Nor & 20 \\
\hline 70 & $\mathrm{Em}$ & Y & Som & 60 \\
\hline 85 & $\mathrm{Mk}$ & $\mathrm{Z}$ & Som & 30 \\
\hline 113 & $\mathrm{Mk}$ & ND & Som & ND \\
\hline 5 & Br.a & $\mathrm{AA}$ & $\mathrm{W}_{y t}$ & 20 \\
\hline 8 & Br.a & $\mathrm{AB}$ & $\mathrm{W}_{y t}$ & 40 \\
\hline 11 & MI & $\mathrm{AC}$ & Wyt & 20 \\
\hline 12 & Br.a & AD & Wyt & 70 \\
\hline 13 & $\mathrm{Mk}$ & $\mathrm{AE}$ & Wyt & 80 \\
\hline 16 & Ar & ND & Wyt & ND \\
\hline 30 & NM & $\mathrm{AF}$ & $\mathrm{W}_{y \mathrm{t}}$ & 60 \\
\hline 300 & NM & ND & Wyt & ND \\
\hline 346 & $\mathrm{Sc}$ & AG & Wyt & 30 \\
\hline 347 & NM & ND & Wyt & ND \\
\hline 420 & Br.a & AH & Wyt & 15 \\
\hline
\end{tabular}

* See footnotes to Table 2.

† Ac, Acinetobacter sp.; Ae, Aeromonas sp.; Ar, Artbrobacter sp.; Br.a, Brevibacter acetylicum; Eh, Er. berbicola; Em, Enterococcus muntii; Kt, K. terrigena; MI, Micrococcus luteus; Mk, Micrococcus kristinae; NM, unidentified Gram-positive; $P$ a, $P$. atreofaciens; $P c, P$. chloroaphis; Pf, P. fluorescens; $\mathrm{Pm}, P$. marginalis; $\mathrm{Pp}, P$. pseudoalcaligenes; $\mathrm{Ps}, P$. syringae; $\mathrm{Pv}, P$. viridiflava; $\mathrm{Sc}$, Staphylococcus carnosus; Xm, Xantbomonas maltophilia. blots. Final washing of the membranes was performed twice in $0.2 \times \mathrm{SSC}, 0.1 \% \mathrm{SDS}$ at $42{ }^{\circ} \mathrm{C}$ unless otherwise stated.

\section{RESULTS}

\section{Natural plasmid isolates}

A collection of bacteria, representative of the phyllosphere microbial community of pre-harvest, mature sugar beet, comprising 29 Enterobacteriaceae, 29 pseudomonads, 2 Acinetobacter spp., 1 Aeromonas sp., 1 Xanthomonas sp. and $17 \mathrm{Gram}$-positive isolates, was assembled from a total of 435 natural isolates. The presence of plasmid DNA in these 79 bacteria had been determined previously by alkali lysis and agarose gel electrophoresis of total DNA (Powell et al., 1993).

\section{Colony hybridization with replicon probes}

All 79 isolates and appropriate controls (Table 1) were subjected to colony blot hybridization with each of the 14 available inc/rep probes. Only 25 of the 79 plasmidcontaining isolates reacted with these probes, and all 25 were identified as members of the Enterobacteriaceae. Six Erwinia isolates hybridized to the repFIIA probe, 18 Erwinia and Klebsiella isolates hybridized to the repFIB probe and one isolate, Er. salicis SBN169, hybridized with both the repFIIA and repFIB probes (Table 2). Two identical plasmid-containing isolates of $\mathrm{Er}$. berbicola, SBN175 and SBN178a, failed to hybridize to any of the probes as did two other isolates, from which plasmid profiles could not be generated; Er. berbicola SBS60 and K. terrigena SBN426. No reactivity was recorded by colony hybridization with any probe against the remaining 50 bacterial isolates screened, comprising $33 \mathrm{Gram}$-negative and 17 Gram-positive bacteria (Table 3). All positive controls hybridized strongly and no false positives were recorded with the plasmid-free isolates tested; E. coli, Pseudomonas putida UWC1, Er. berbicola Eh5 and P. aureofaciens SBW25. Care was taken during lysis and preparation of the membranes to optimize the retention of DNA and sensitivity of the assay. Under normal conditions of alkali lysis and denaturation (Maniatis et al., 1982), poor specificity was observed, the pseudomonadpositive controls (RP4 and R300B) often gave only weak hybridization and Gram-positive colonies floated off the membrane support. Application of the microwave heating step was essential for optimizing sensitivity and lysing the Gram-positive colonies. Optimal sensitivity was considered important as the copy number of many natural plasmids can be low and therefore diminish the quantity of available target. To confirm the specificity of the replicon probes, the plasmid DNA extracted from the pseudomonad isolates was digested with $P_{s t} \mathrm{I}$, the fragments separated on an agarose gel, transferred to a nylon membrane and hybridized with radiolabelled replicon

$\ddagger$ See footnotes to Table 2 .

$\S$ See footnotes to Table 2. Som, Somerset.

\| See footnotes to Table 2. 
(a)

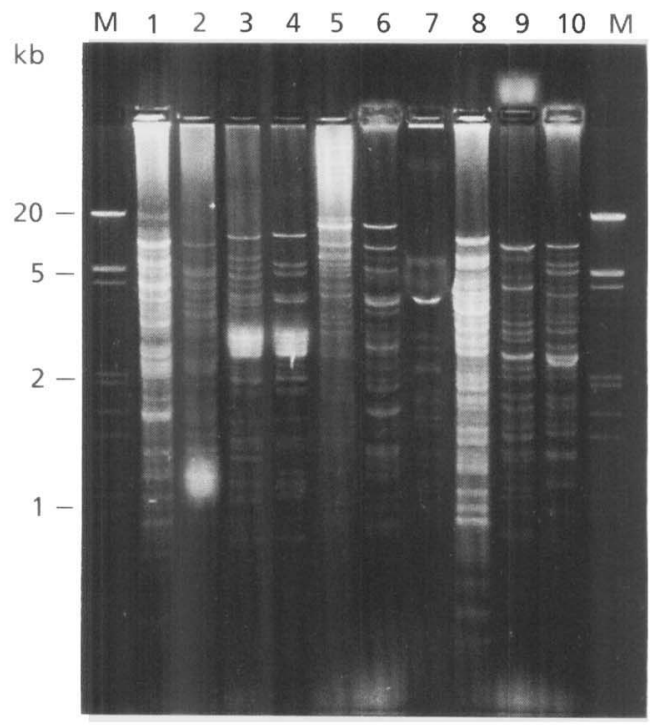

(b)

$\mathrm{kb}$

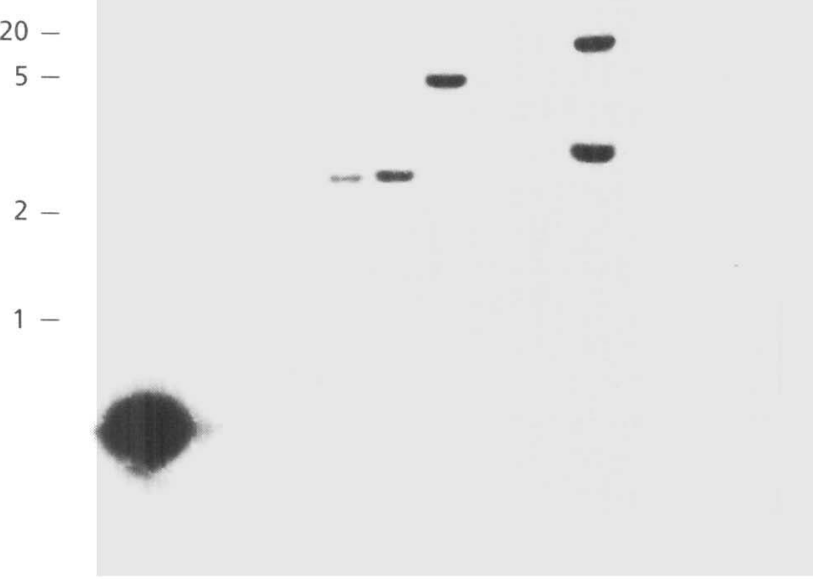

(c)

$\mathrm{kb}$

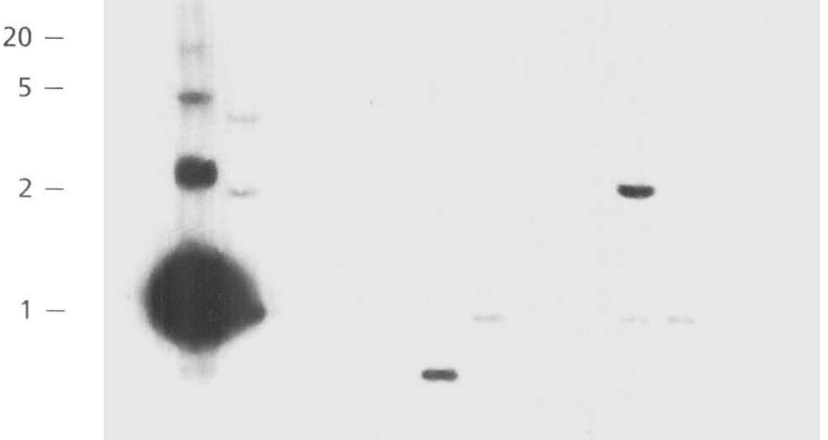

probes as described above. No reactivity with these samples was recorded (negative data not shown).

Total DNA extracted from each sample was also investigated by dot-blot hybridization to confirm that sufficient DNA for detection was released from the bacterial cells in the colony blotting protocol. Bound genomic DNA was hybridized with the available inc/rep probes as described for the colony blot method. The results from the two assays were in agreement and no increase in sensitivity was observed with the dot-blot method. Due to its relative simplicity, the adapted colony blot method was the method of choice for the primary screen. To further demonstrate that the lack of hybridization recorded with the non-Enterobacteriaceae in the plasmid collection was not due to the analysis of an unrepresentative sample, further examinations were undertaken. Bacteria were washed from the leaves and roots of mature sugar beet plants grown in an experimental plot at Wytham, Oxfordshire, and isolated on TSBA. The colonies were replicated onto membrane filters and hybridized with mixtures containing up to four different inc/rep probes to minimize the number of filters tested. Samples collected on three separate occasions, 150, 200 and $250 \mathrm{~d}$ after planting, were diluted and twenty $150 \mathrm{~mm}$ Petri-dishes each supporting up to 5000 colonies were examined by colony blotting. Reactivity was only recorded with the repF probe mixture. The plasmid content of these reactive colonies was not examined.

\section{Restriction endonuclease characterization of natural plasmid isolates}

Using mini-preparation methods only, plasmid DNA of sufficient quantity and quality to permit digestion with Pst I was obtained from 64 out of 79 isolates. These 64 isolates were divided into $34 \mathrm{REN}$ (restriction endonuclease) groups according to the total plasmid DNA profiles observed (Tables 2 and 3). Particular isolates were represented more than once, indicating their relative abundance in the sampled habitat. One plasmid group, type isolate $K$. terrigena SBW2, represented a third of all the isolates examined and 11 out of 13 of the plasmidcontaining Enterobacteriaceae collected from the Wytham site. Each REN group was found to be unique to the site from which the samples were collected. Plasmid presence in the 15 isolates refractory to restriction endonuclease digestion, was confirmed as large bands migrating behind chromosomal DNA after agarose gel electrophoresis. Whether the inability to generate plasmid profiles in these 15 isolates was due to poor extraction, low copy number or plasmid instability was not deter-

Fig. 1. Restriction fragment profiles and Southern hybridization of Pstl-digested total plasmid DNA purified from Enterobacteriaceae isolated from the leaves of mature sugar beet plants. (a) Ethidium-bromide-stained $0.8 \%$ agarose gel. (b, c) Autoradiograms of plasmid DNA hybridized to the $543 \mathrm{bp}$ repFIIA (b) or the 1202 bp repFIB (c) replicon probes. Lanes: 1, SBW2; 2, SBN130; 3, SBN139; 4, SBN153; 5, SBN169; 6, SBN170; 7, SBN175; 8, SBN178b; 9, SBW353; 10, SBW385; M, ECoRI- and HindlII-digested $\lambda$ DNA; i, FIIA fragment; ii, FIB fragment. 
mined. Estimates of the size of plasmids extracted from non-Enterobacteriaceae were below $100 \mathrm{~kb}$ in all but one instance (Table 3), which may further indicate a limitation in the extraction method for large plasmids in quantities suitable for REN grouping.

\section{Characterization of replicon probe reactive plasmids by agarose gel electrophoresis and Southern hybridization}

The Erwinia and Klebsiella isolates (Table 2) were analysed as described above and divided into 10 different REN groups (Fig. 1a). The total size of plasmid DNA in each isolate was estimated from the fragment size aggregate (Table 2). Visual comparison of the relative molar masses of each restriction fragment observed indicated that most, if not all, of the isolates contained more than one plasmid species (Fig. 1a). The repFIB reactive plasmids were the most common and identified in samples collected at both the Northampton and Wytham sites. Plasmids homologous to the repFIIA probe were only isolated from plants grown in Northampton.

The plasmid fragments that hybridized to the incF probes were identified by Southern blotting (Fig. 1b). Strong homology was observed between the incF probes and 9 of the 10 plasmid groups isolated from Klebsiella or Erwinia species. Different isolates contained hybridizing DNA fragments of similar size; for example, the repFIB probe hybridized with $1 \mathrm{~kb}$ Pst $\mathrm{I}$ fragments in isolates collected from Northampton (SBN2, SBN130, SBN170) and Wytham, Oxfordshire (SBW353, SBW383). The apparent homology between these fragments and the FIB probe and the recent report comparing repFIB sequence data from nine otherwise unrelated clinical plasmid isolates (Spiers \& Bergquist, 1992), indicates that this replicon may be highly conserved in the Enterobacteriaceae.

Heterogeneity within the plasmid population isolated from leaves was evident when DNA profiles were compared. For example, the total plasmid DNA profile from SBN139 (REN group B) contained several Pst fragments in addition to all of those observed in isolate SBN153 (REN group C). As REN group B isolates contained an estimated $50 \mathrm{~kb}$ of plasmid DNA in addition to that found in group $\mathrm{C}$ isolates (Table 2, Fig. 1a) they were provisionally placed in separate REN groups. The isolates in these two REN groups contained a common $2.64 \mathrm{~kb}$ Pst I fragment that hybridized to repFIIA (Fig. 1b). SBN169 (REN group D) reacted strongly with both the repFIIA and repFIB probes (Fig. 1b, c). Two reactive fragments were also observed in SBN178b probed with repFIIA (Fig. 1b, lane 8), indicating that either a PstI site was located within the homologous region or two or more compatible plasmids were present. As FIIA probes share homology with other rep probes it was not possible to determine whether the plasmid isolates, SBN139, SBN153, SBN178b or SBN169 belonged to the incFIIA, incFIC or the com9 group. Couturier et al. (1988) observed that the replicons associated with repFIIA, rep9, repFIC, repI1, repB/O and repK were all phylogenetically related. However, as no reactivity was observed between the
repB/O probe and the phylloplane isolates described here it was concluded that these natural plasmids may contain genes analogous to the repA2 genes (Saadi et al., 1987) and therefore can be classified into either the com 9 or IncFII incompatibility groups.

\section{DISCUSSION}

Previous studies into the microbial ecology of sugar beet phyllosphere have demonstrated that it supports a varied and diverse bacterial community (Thompson et al., 1993). In common with other phytosphere habitats (Farrad, 1989; Shaw, 1987; Coplin et al., 1981), many of the bacteria isolated from sugar beet contain plasmids. The majority of plasmids so far described in these natural habitats carry antibiotic resistance genes or virulence determinants which have aided the isolation and selection of host bacteria. In the absence of known selectable traits, however, plasmid-containing bacterial isolates have to be identified by cell lysis and the purification of plasmid DNA. This approach can be time consuming and imprecise. Although it is suitable as a general method for extracting plasmid DNA from a diverse collection of bacteria, it may result in underestimation of plasmid abundance. More detailed studies into selected groups of bacteria, for which reliable extraction methods can be developed, may eventually result in estimates of plasmid content closer to $100 \%$ for certain Gram-negative populations. Our initial investigations provided an estimate that only $33 \%$ of the sampled Erwinia or Klebsiella populations contain plasmids (Powell et al., 1993), when the study was extended specifically to focus on this component of the phytosphere bacterial community the percentage of bacteria supporting plasmids varied between $30 \%$ and $90 \%$, depending on the source of samples and growth stage of the plant from which the samples were taken (N. Kobayashi, unpublished observations). To facilitate the detection of otherwise cryptic plasmids, molecular probes, from well characterized isolates, need to be developed and assessed. Such an approach would be relevant for the detection of related plasmids from unique or poorly studied habitats.

In this study the extent of homology between the replicon probes of Couturier et al. (1988) and natural phyllosphere plasmids was found to be limited to Erwinia and Klebsiella isolates which reacted with the repFIB and repFIIA probes. The lack of homology recorded between the nonincF probes and the characterized isolates or the bacterial colonies collected from bulked leaf samples demonstrates that plasmids in the natural environment contain replication and maintenance genes which are different from those currently defined. This lack of homology between the incompatibility groups demonstrates the limitations of the current classification system and the apparent diversity of environmental plasmids.

The replicon probes used in this investigation were developed to highly conserved incompatibility regions and have been successfully applied in the characterization of clinical isolates containing one or more replicon 
(Couturier et al., 1988; Pohl et al., 1991; Gibbs et al., 1993). In the few studies that report the use of these replicon probes to classify hospital or animal plasmid isolates they have been found to function reliably when compared to standard mating methodologies for determining incompatibility groups (Chaslus-Dancla et al., 1991; Da Silva-Tatley \& Steyn, 1993). In a comparative study of enteropathogenic $E$. coli strains, which included a control sample of 65 environmental coliforms isolated from a sewage outlet, it was demonstrated that the plasmid-containing strains only reacted with the IncF replicon probes (Hales et al., 1992). Although the plasmid content of the 65 environmental coliforms was not determined, only four of the isolates reacted, one against IncFIA and three against IncFIC (Hales et al., 1992). Until further studies into the incompatibility grouping of plasmids indigenous to a wider range of habitats are undertaken the extent of the heterogeneity of plasmid replicons outside the clinical environment will remain unresolved.

In this study we have demonstrated that colony blotting, provides a simple, accurate and reliable method for characterizing natural isolates. Where necessary, further differentiation of isolates of similar Inc groups has been based on restriction fragment length polymorphism although, as demonstrated by Gibbs et al. (1993), sequence analysis of closely related replicons would permit comparison of evolutionary relationships between isolates. We have also demonstrated that the RepFIB and RepFIIA replicons are common to members of the Enterobacteriaceae colonizing sugar beet leaves indicating that these replicons are highly conserved in a number of different plasmids from a variety of habitats. The lack of homology recorded with the known replicon probes prevented the further classification of the majority of the isolates into recognized incompatibility groups. Studies are currently under way to isolate and identify the corresponding loci and to develop probes for the detection of phytosphere plasmids.

\section{ACKNOWLEDGEMENTS}

We thank Professor W. K. Maas and Dr M. Couturier for kindly providing the plasmids bearing the inc/rep probes; N.K. was supported on a research grant awarded by the Ministry of Agriculture Fisheries and Food.

\section{REFERENCES}

Ausubel, F. M., Brent, R., Kingston, R. E., Moore, D. D., Seidman, J. G., Smith, J. A. \& Struhl, K. (1989). Current Protocols in Molecular Biology. New York: John Wiley \& Sons.

Bailey, M. J. \& Thompson, I.P. (1992). Detection systems for phyllophane pseudomonads. In Genetic Interactions Between Microorganisms in the Microenvironment, pp. 126-141. Edited by F. M. Wellington \& J. D. van Elsas. Oxford: Pergamon Press.

Bergquist, P. L. (1987). Incompatibility. In Plasmids: a Practical Approach, pp. 37-78. Edited by K. G. Hardy. Washington, DC: IRL Press.

Buluwela, L., Forster, A., Boehm, T. \& Rabbitts, T. H. (1989). A rapid procedure for colony screening using nylon filters. Nucleic Acids Res 17, 452.
Chaslus-Dancla, E., Pohl, P., Meurisse, M., Marin, M. \& Lafont, J. P. (1991). High genetic homology between plasmids of human and animal origins conferring resistance to the aminoglycosides gentamicin and apramycin. Antimicrob Agents Chemother 35, 590-593.

Coplin, D. L., Rowan, R. G., Chisholm, D. A. \& Whitmoyer, R. E. (1981). Characterization of plasmids in Erwinia stewartii. Appl Environ Microbiol 42, 599-604.

Couturier, M., Bex, F., Bergquist, P. L. \& Maas, W. K. (1988). Identification and classification of bacterial plasmids. Microbiol Rev 52, 375-395.

Da Silva-Tatley, F. M. \& Steyn, L. M. (1993). Characterization of the moderately promiscuous plasmid, pGSH5000, with features of both the mini replicon of pCU1 and the ori-2 of F. Mol Microbiol 7, 805-823.

Datta, N. (1979). Plasmid classification: incompatibility grouping. In Plasmids of Medical, Environmental and Commercial Importance, pp. 3-12. Edited by K. N. Timmis \& A. Puhler. Amsterdam: Elsevier.

Davey, R. B., Bird, P. I., Nikoletti, S. M., Prazkier, J. \& Pittard, J. (1984). The use of mini-gal plasmids for rapid incompatibility grouping of conjugative R plasmids. Plasmid 11, 234-242.

Farrad, S. K. (1989). Conjugal transfer of bacterial genes on plants. In Gene Transfer in the Environment, pp. 261-285. Edited by S. B. Levy \& R. V. Miller. New York: McGraw-Hill.

Frischer, M. E., Thurmond, J. M. \& Paul, J.H. (1990). Natural plasmid transformation in a high frequency of transformation marine Vibrio strain. Appl Environ Microbiol 56, 3439-3444.

Fry, J. C. \& Day, M. J. (1990). Plasmid transfer in the epilithon. In Bacterial Genetics in Natural Environments, pp. 55-80. Edited by J. C. Fry \& M. J. Day. London: Chapman and Hall.

Gibbs, M. D., Spiers, A. J. \& Bergquist, P. L. (1993). RepFIB: a basic replicon of large plasmids. Plasmid 29, 165-179.

Hales, B. A., Hart, C. A., Batt, R. M. \& Saunders, J. R. (1992). The large plasmids found in enterohemorrhagic and enteropathogenic Escherichia coli constitute a related series of transfer defective IncFIIA replicons. Plasmid 28, 183-193.

Hill, K. E., Weightman, A. J. \& Fry, J. C. (1992). Isolation and screening of plasmids from the epilithon which mobilize recombinant plasmid from pD10. Appl Environ Microbiol 58, 1292-1300.

Kado, C. I. \& Liu, S.-T. (1981). Rapid procedure for detection and isolation of large and small plasmids. J Bacteriol 145, 1365-1373.

McClure, N. C., Weightman, A. J. \& Fry, J. C. (1989). Survival of Pseudomonas putida UWC1 containing cloned catabolic genes in a model activated-sludge unit. Appl Environ Microbiol 55, 2627-2634.

Maniatis, T., Fritsch, E. F. \& Sambrook, J. (1982). Molecular Cloning: a Laboratory Manual. Cold Spring Harbor, NY: Cold Spring Harbor Laboratory.

Novick, R. P. (1987). Plasmid incompatibility. Microbiol Rev 51, 381-395.

Ohta, M., Arakawa, Y., Kido, N., Komatsu, T., Okamoto, K., Sekizaki, T. \& Kato, N. (1989). An Introduction to New Recombinant DNA Tecbniques. Tokyo, Japan: Saikon Publishing Co.

Pohl, P., Lintermans, P., Marin, M. \& Couturier, M. (1991). Epidemiologic study of Salmonella enteritidis strains of animal origin in Belgium. Epidemiol Infect 106, 11-16.

Powell, B. J., Purdy, K. J., Thompson, I. P. \& Bailey, M. J. (1993). Demonstration of tra $^{+}$plasmid activity in bacteria indigenous to the phyllosphere of sugar beet; gene transfer to a recombinant pseudomonad. FEMS Microbiol Ecol 12, 195-206.

Saadi, S., Maas, W. K., Hill, D. F. \& Bergquist, P. L. (1987). Nucleotide sequence analysis of RepFIC, a basic replicon present in 
IncFI plasmids P307 and F and its relation to RepA replicon of IncFII plasmids. J Bacteriol 169, 1836-1846.

Shaw, P. D. (1987). Plasmid ecology. In Plant-Microbe Interactions. Molecular and Genetic Perspectives, vol. 2, pp. 3-39. Edited by T. Kosuge \& E. W. Nester. New York: Macmillan.

Spiers, A. J. \& Bergquist, P. L. (1992). Expression and regulation of the RepA protein of the repFIB replicon from plasmid P307. I Bacteriol 174, 7533-7541.

Stead, D. E., Sellwood, J. E., Wilson, J. \& Viney, I. (1992). Evaluation of a commercial microbial identification system based on fatty acid profiles for rapid, accurate identification of plant pathogenic bacteria. J Appl Bacteriol 72, 315-321.
Thompson, I. P., Bailey, M. J., Fenlon, J. S., Fermor, T. R., Lilley, A. K., Lynch, J. M., McCormack, P. J., McQuilken, M., Purdy, K. J., Rainey, P. B. \& Whipps, J. M. (1993). Quantitative and qualitative seasonal changes in the microbial community from the phyllosphere of sugar beet (Beta vulgaris). Plant Soil 150, 177-191.

Top, E., Mergeay, M., Springael, D. \& Verstraete, W. (1990). Gene escape model: transfer of heavy metal resistance genes from Escherichia coli to Alcaligenes eutrophus on agar plates and in soil samples. Appl Environ Microbiol 56, 2471-2479.

Received 1 March 1993; revised 12 August 1993; accepted 17 August 1993. 